\title{
IMPLEMENTASI PELAYANAN KUNJUNGAN BERBASIS INFORMATION TECHNOLOGY (IT) DI LAPAS PEREMPUAN KELAS IIA DENPASAR
}

\author{
SITI NGATIQOH \\ Politeknik Ilmu Pemasyarakatan Depok, Indonesia \\ Email: sitingatiqoh96@gmail.com
}

\begin{abstract}
This research focuses on the implementation of Information Technology (IT) based visitation services at Women Prison Class IIA Denpasar and the constraints that inhibit Information Technology (IT) based visitation services. The research method used is descriptive with qualitative approach. Data collection techniques used are by observation, interview, bibliography and documentation study. After conducting research at Women Prison Class IIA Denpasar, the authors obtained the result that Implementation of IT-based visit services at Women Prison Class IIA Denpasar has been implemented in accordance with the procedures, the faster service, the visitors are given a comfortable place, the openness was given in accordance with the portion, so that although there are still shortcomings but can be minimized with honest, fast, and good service. The process of visiting service has been more effective, especially to overcome the illegal fees that have been happening to accelerate the service process, with already integrated with IT services provided can be run with more orderly. Behind the many changes that are certainly considered better by the community especially those who receive the visit service, but there are still obstacles that still hamper the implementation of IT-based visit services such as the internet network which is sometimes not smooth, lack of visitor knowledge about the use of technology and lack of facilities and infrastructure.
\end{abstract}

Keywords: IT-based Visit Service; Correctional Institution.

Abstrak. Penelitian ini fokus pada pelaksanaan pelayanan kunjungan berbasis Teknologi Informasi (IT) di Lembaga Pemasyarakatan Perempuan Kelas IIA Denpasar dan kendala yang menjadi penghambat pelayanan kunjungan berbasis Teknologi Informasi (IT). Adapun metode penelitian yang digunakan adalah deskriptif dengan pendekatan kualitatif. Teknik pengumpulan data yang digunakan adalah dengan observasi, wawancara, kepustakaan dan studi dokumentasi. Setelah melakukan penelitian di Lembaga Pemasyarakatan Perempuan Kelas IIA Denpasar, penulis memperoleh hasil bahwa implementasi pelayanan kunjungan yang berbasis IT di Lembaga Pemasyarakatan Perempuan Kelas IIA Denpasar sudah diterapkan sesuai dengan prosedurnya, pelayanan berlangsung cepat, pengunjung diberikan tempat yang nyaman, keterbukaan pun diberikan sesuai dengan porsinya, sehingga walaupun masih terdapat kekurangan namun dapat diminimalisir dengan pelayanan yang jujur, cepat, dan baik. Proses pelayanan kunjungan sudah lebih efektif terutama mengatasi pungutan liar yang selama ini terjadi untuk mempercepat proses pelayanan, dengan telah teritegrasikan dengan IT pelayanan yang diberikan sudah dapat dijalankan dengan lebih tertib. Di balik banyaknya perubahan yang tentunya dianggap lebih baik oleh masyarakat khususnya yang menerima pelayanan kunjungan tersebut, namun masih terdapat kendala yang masih menghambat pelaksanaan pelayanan kunjungan yang berbasis IT seperti jaringan internet yang terkadang tidak lancar, kurangnya pengetahuan pengunjung tentang penggunaan teknologi dan kurangnya sarana dan prasarana.

Kata Kunci: Pelayanan Kunjungan Berbasis IT; Lembaga Pemasyarakatan. 


\section{PENDAHULUAN}

Kemajuan zaman memicu perubahan dan perbaikan berbagai bidang. Tak terkecuali kemajuan di bidang pelayanan pemerintahan yang ditandai dengan sangat mencolok oleh penggunaan teknologi dan informasi demi meningkatkan pelayanan publik. Demi beradaptasi dengan kemajuan dan penggunaan teknologi, maka diperlukan syarat yang mencakup reformasi birokrasi, restrukturisasi organisasi dan sumber daya manusia, peningkatan pelayanan yang efektif, transparan dan akuntabilitas, dan penguatan regulasi kelembagaan. Reformasi birokrasi membutuhkan sikap keterbukaan dan adaptif dengan dinamika kemajuan lingkungan. Hal ini untuk meningkatkan fungsi birokrasi secara cepat, tepat, efektif dan efisien. Sementara ini, ada kesenjangan antara harapan birokrasi ideal dengan realitas birokrasi yang ada.

Terkait ini, lembaga pemasyarakatan (Lapas) sebagai unit pelaksana teknis di Direktorat Jenderal Pemasyarakatan, Kementeiran Hukum dan Hak Asasi Manusia Republik Indonesia (Kemenkumham RI) melakukan perbaikan dan peningkatan pelayanan untuk mengikuti kemajuan zaman sejalan dengan UU No.14 Th. 2008 tentang Keterbukaan Informasi Publik sebagai Pendukung Pemberian Layanan Kunjungan Yang Efektif. Program yang akan dimulai pada 30 April 2010. berbasis Information Technology (IT). Ini membantu efektifitas pekerjaan dalam hal membuat, menyimpan, mengubah, mengkomunikasikan dan/atau menyebarluaskan informasi. Dengan kecepatan tinggi, komunikasi data, suara dan video disatukan oleh IT. Dalam pengembangannya, lapas membuat sebuah aplikasi guna memudahkan proses jalannya pemasyarakatan dibuatlah Sistem Database Pemasyarakatan (SDP).

SDP adalah database yang menunjang kinerja cepat, efisien, dan tepat serta memberikan informasi yang lengkap. SDP meningkatkan kualitas dan memperlancar pelayanan kunjungan. Pengunjung dibuat nyaman dengan kemudahan prosedur pelayanan yang cepat. Pengembangan pengelolaan dan penyediaan informasi publik oleh Dirjen Pemasyarakatan ini sejalan dengan regulasi yang tertuang di dalam Permenkumham No. M.HH-01-IN.04.03 tahun 2011 serta didukung Permenkumham No. 39/2016 tentang Sistem Database Pemasyarakatan (SDP).

Perubahan pelayanan kunjungan melalui SDP terlihat dari pengambilan nomor antrian, pendaftaran melalui komputer hingga pengecekan durasi waktu kunjungan yang terkelola dengan lebih baik. Hal ini beda jauh dari pengelolaan 
kunjungan sebelum adanya SDP, semua dilakukan secara manual, tidak efektifefisien sehingga pengunjung merasa pelayanan yang diberikan belum memadai.

\section{METODE}

Penelitian ini menggunakan metode kualitatif, yaitu bertujuan untuk memahami peristiwa yang dialami oleh subjek penelitian, seperti perilaku, persepsi, motivasi, tindakan, dan lain-lain secara holistik, dan dengan deskripsi sebagai cara dalam membentuk kata-kata dan bahasa pada suatu bagian khusus yang alamiah dan dengan memanfaatkan berbagai metode alamiah (Moleong, 2007:6).

Sumber data pada penelitian ini diperoleh dari Ketua Lapas Kelas IIA Denpasar, Kasie Binadik, Kasubsie Registrasi, masyarakat yang melakukan kunjungan langsung dan merasakan pelayanan kunjungan yang diberikan oleh Lapas Perempuan Kelas IIA Denpasar, narapidana dan tahanan yang merupakan hak dasarnya menerima kunjungan sebagai wujud reintegrasi untuk pemulihan hubungannya dengan keluarga, serta pegawai Lapas Pemasyarakatan Perempuan Kelas IIA Denpasar yang bertugas sebagai pelaksana kegiatan pemberian layanan kunjungan.

Data primer diperoleh melalui interview/wawancara dan observasi. Sedangkan data sekunder diperoleh melalui penelusuran kepustakaan dan studi dokumentasi. Hasil penelitian yang diperoleh baik dari data primer maupun data sekunder kemudian dianalisis secara kualitatif dan disajikan secara deskriptif yaitu menjelaskan, menguraikan, dan menggambarkan permasalahan relevansinya dengan penelitian ini.

\section{HASIL DAN DISKUSI}

\section{Implementasi Pelayanan Kunjungan Berbasis IT}

Pelayanan kunjungan pada Lembaga Pemasyarakatan Perempuan Kelas IIA Denpasar saat ini menggunakan Information Technology (IT) yaitu berupa aplikasi Sistem Database Pemasyarakatan (SDP).SDP membantu mempermudah pelaksanaan pelayanan kunjungan. Pelayanan kunjungan berbasis IT sudah dilaksanakan sesuai dengan alur kunjungan yang berlaku. 
Tabel 1.1 Jadwal Layanan Kunjungan di Lembaga Pemasyarakatan Perempuan Kelas II A Denpasar

\begin{tabular}{ccc}
\hline No & Hari & Jam \\
\hline 1 & Senin & $09.00-11.30$ dan $13.00-14.30$ \\
\hline 2 & Selasa & $09.00-11.30$ dan $13.00-14.30$ \\
\hline 3 & Rabu & $09.00-11.30$ dan $13.00-14.30$ \\
\hline 4 & Kamis & $09.00-11.30$ dan $13.00-14.30$ \\
\hline 5 & Jumat & $09.00-11.30$ dan $13.00-14.30$ \\
\hline
\end{tabular}

Sumber: sub sie registrasi Lapas Perempuan Kelas IIA Denpasar

Dalam prosedurnya, diawali dengan pengunjung mengambil nomor antrian untuk registrasi, lalu dipanggil petugas sesuai nomor urut sekaligus menyerahkan nomor urut tersebut kepada petugas. Pengunjung lalu ditanya identitas WBP yang akan dikunjungi. Setelah itu, petugas menginput data pengunjung mulai dari nomor identitas pengunjung, nama pengunjung, jenis kelamin, hubungan dengan WBP, alamat pengunjung, berapa jumlah yang akan masuk ke dalam, dan barang bawaan apa saja. SDP lalu mencetak informasi yang baru saja diinput dan seterusnya pengunjung menerima surat izin kunjungan. Setelah itu, pemanggilan pengunjung secara otomatis menggunakan fitur SDP.

Pengunjung yang akan masuk dilengkapi kalung akses masuk ke ruang besukan. Pengunjung dan barang bawaannya digeledah menggunakan mesinX-ray yang mendeteksi barang-barang yang tidak boleh dibawa ke dalam Lapas seperti senjata tajam maupun narkoba. Setelah semua prosedur itu, barulah pengunjung dipersilahkan menuju ruang kunjungan yang tersedia, dan menunggu WBP yang sudah dipanggil. WBP yang dibesuk melapor kepada petugas. Pengunjung wajib mengambil barang yang dititipkan dan mengembalikan kalung kunjungan untuk mengambil kartu identitasnya kembali setelah selesai kunjungan. Saat penelitian ini berlangsung, jumlah pengunjung Lapas setiap harinya berkisar 50-60 nomor antrian. Jumlah pengunjung tertinggi terjadi pada Senin dan Jumat. Sedangkan Sabtu dan Minggu tidak ada kunjungan. 


\section{Tabel 1.2 Jumlah Tahanan dan Narapidana di Lembaga Pemasyarakatan} Perempuan Kelas II A Denpasar 12 Juni 2019

\begin{tabular}{cccc}
\hline No & Jenis & Isi & Jumlah \\
\hline 1 & Tahanan & 63 & \multirow{2}{*}{197} \\
\cline { 1 - 3 } 2 & Narapidana & 134 & \\
\hline
\end{tabular}

Sumber: Sub Seksie Registrasi

\section{Tabel 1.3 Jumlah Pengunjung di Lembaga Pemasyarakatan Perempuan Kelas II A Denpasar}

\begin{tabular}{ccc}
\hline No & Hari/Tanggal & Jumlah Pengunjung \\
\hline 1 & Senin, 10 Juni 2019 & 72 Orang \\
\hline 2 & Selasa, 11 Juni 2019 & 57 Orang \\
\hline 3 & Rabu, 12 Juni 2019 & 47 Orang \\
\hline 4 & Kamis, 13 Juni 2019 & 56 Orang \\
\hline 5 & Jum'at, 14 Juni 2019. & 75 Orang \\
\hline 6 & Senin, 17 Juni 2019 & 67 Orang \\
\hline 7 & Selasa, 18 Juni 2019 & 65 Orang \\
\hline
\end{tabular}

Sumber: Subsie Registrasi Lembaga Pemasyarakatan Perempuan Kelas IIA Denpasar

Serupa dengan Unit Pelaksana Teknis Pemasyarakatan yang lain, sesudah selesai melaksanakan kunjungan di lapas Perempuan Kelas IIA Denpasar, mereka (pengunjung) memasukkan kartu kepuasan pelayanan kunjungan ke dalam kotak yang telah disediakan. Kartu tersebut berisi 3 pilihan terhadap pelayanan kunjungan yaitu Puas, Kurang puas, dan Tidak puas. Setelah semua pengunjung selesai dan jam kunjung habis, petugas menghitung hasil dari kotak kepuasan pengunjung dan dibuat laporan untuk nanti sebagai bahan evaluasi demi peningkatan pelayanan kunjungan.

Kotak tingkat kepuasan pengunjung tersebut masih berbentuk manual. Dengan pelayanan kunjungan yang berbasis IT, bentuk penilaian pengunjung atas tingkat kepuasan layanan seharusnya juga berbasis IT, misalkan menggunakan layar yang memiliki kecanggihan Touch Screen. Pengunjung tinggal menekan pilihan di layar dan terinput secara otomatis. Selain lebih praktis, hal itu juga memberikan kenyamanan terhadap pengunjung sebab sangat kecil bagi orang lain untuk melihat jawaban pengunjung. Selama bulan Juni 2019, jumlah pengunjung Lapas Perempuan Kelas IIA Denpasar yang merasa puas mencapai $74,86 \%$, kurang puas $21,08 \%$, dan tidak puas 3,78\%. 
Pelaksanaan pelayanan kunjungan berbasis IT pada Lapas Kelas IIA Denpasar berjalan sesuai dengan jadwal yang telah ditentukan. Kunjungan dilaksanakan pada hari Senin sampai dengan hari Jum'at. Kunjungan libur pada saat hari besar nasional, kecuali Hari Raya. Bagi pengunjung yang akan membesuk WBP tetapi tidak membawa surat izin kunjungan dari pihak yang menahan, maka pengunjung tidak diperbolehkan masuk, dan setiap pengunjung wajib menaati tata tertib kunjungan.

Berdasarkan hasil observasi, Lapas Perempuan Kelas IIA Denpasar sudah memprogramkan pelayanan kunjungan berbasis IT dalam bentuk video call. Pelayanan kunjungan video call dan pendaftaran kunjungan daring menggunakan whatsapp sudah diterapkan dan merupakan inovasi dari Lapas Perempuan Kelas IIA Denpasar. Kunjungan daring dan pelayanan kunjungan berbentuk video call pada dasarnya adalah untuk pengunjung dan warga binaan itu sendiri, apabila pengunjung dapat menggunakannya terutama pendaftaran daring, maka hal itu pun akan mempercepat pelayanan pendaftaran yang ada.

Mengenai pelayanan kunjungan dengan bentuk video call, baru dilakukan oleh sebagian warga binaan saja. Hal ini terjadi akibat dari pengunjung yang kurang mengerti teknologi. Baru sedikit pengguna video call karena hanya sedikit pengunjung yang menggunakan dan karena kurangnya sosialisasi sehingga sosialisasi pun harus dilakukan. Pelayanan kunjungan berbentuk daring sudah dilakukan hal, ini memberikan kemudahan para pengunjung untuk melakukan pendaftaran secara langsung dan pada hari kunjungan hanya tinggal dilaksanakan penggeledahan barang dan orang.

Dari segi pelayanan kunjungan yang diberikan oleh Lembaga Pemasyarakatan sudah berjalan dengan baik. Dibuktikan dengan tingginya tingkat kepuasan pengunjung, hanya sedikit pengunjung yang merasa kurang puas dan tidak puas. Kemudian hasil wawancara dan hasil obervasi yang penulis lakukan terkait dengan bagaimana pelayanan yang sekarang dirasakan apakah lebih baik terhadap masyarakat dan WBP sebagai yang merasakan langsung pelayanan tersebut, dapat disimpulkan sudah lebih baik dari proses sebelumnya karena banyak kekurangan yang sekarang sudah terpenuhi dengan pelayanan berbasis IT.

Implementasi pelayanan kunjungan berbasis IT ini juga dianggap oleh petugas sudah dapat banyak membantu tugas mereka dalam memberikan pelayanan yang lebih baik lagi, yang sebelumnya serba manual sekarang sudah 
ditunjang dengan perangkat elektronik untuk mempermudah tugas mereka dalam memberikan pelayanan yang lebih baik lagi. Dan pemenuhan informasi sudah dapat cepat diberikan kepada pengunjung tanpa proses yang berbelitbelit lagi, sekarang semuanya lebih cepat dan efisien.

\section{Penghambat Pelaksanaan Pelayanan Kunjungan Berbasis Information Technology di Lembaga Pemasyarakatan Kelas IIA Denpasar}

Di balik banyaknya perubahan yang dianggap lebih baik oleh masyarakat khususnya yang menerima pelayanan kunjungan tersebut, ada beberapa hal yang masih belum dapat diterapkan dan kurang optimal dalam pemberian pelayananyang cepat dan efektif. Pertama, jaringan internetyang tidak lancar jadi penghambat proses kunjungan. Dengan kendala koneksi internet, maka aplikasi SDP tidak bekerja dengan baik. Kedua, kurangnya pengetahuan pengunjung tentang IT. Banyak dari WBP yang dikunjungi orang tuanya dengan usia di atas 50 tahun. Mereka tidak mengerti menggunakan layanan video call maupun pendaftaran online untuk kunjungan. Akibatnya, tidak semua pengunjung bisa menggunakan pelayanan tersebut. Ketiga, sarana dan prasarana, ruang kunjungan yang tidak seimbang dengan jumlah pengunjung. Sedikitnya kursi di ruang kunjungan dan hanya tedapat 1 kipas angin. Selain itu, kadang printer petugas tidak dapat digunakan yang berakibat hambatan pelayanan sehingga pengunjung harus mengisi secara manual.

\section{Interpretasi Hasil Penelitian}

Dalam penelitian ini, pelayanan kunjungan yang dilaksanakan oleh lapas Kelas IIA Denpasar sejalan dengan Undang-undang Nomor 25 Tahun 2009 tentang Pelayanan Publik. Selain itu, pelayanan ini juga didukung dengan Information Technology (IT) yang membuat pelayanan jadi lebih baik. Hal ini berkaitan dengan SERVQUAL (Service Quality) yang dikembangkan oleh Parasuraman, Zeithaml, dan Berry. Terdapat lima dimensi SERVQUAL, yaitu: Pertama, Tangibles (bukti fisik), dalam hal ini, sarana dan prasarana di Lapas Kelas IIA Denpasar masih kurang, printer terkadang error, dan begitu pun dengan jaringan internetnya. Soal gedung di Lembaga Pemasyarakatan Kelas IIA Denpasar, sudah ada ruangan tersendiri untuk pendaftaran kunjungan namun dalam pemberian ruang kunjungannya masih dirasa perlu diperluas 
untuk memenuhi kenyamanan dalam berkunjung.

Sarana teknologi, peralatan yang digunakan yaitu 3 buah komputer, 2 komputer untuk meginput Sistem Database Pemasyarakatan, dan komputer lainnya adalah komputer server, printer, jaringan komputer, pengeras suara, satu buah kipas angin dan satu buah televisi. Untuk video call terdapat 5 buah tablet di samping ruang kunjungan, untuk pendaftaran online walaupun sudah ada tetapi tidak terintegrasi langsung kepada SDP. Mengenai penampilan pegawai, berdasarkan observasi yang penulis lakukan, penampilan pegawai pada Lembaga Kelas IIA Denpasar bersih dan rapi, dan selalu mengenakan pakaian dinas sesuai dengan ketentuan yang berlaku.

Kedua, Reliability (kehandalan), kemampuan lapas untuk memberikan pelayanan sesuai yang dijanjikan secara akurat dan terpercaya. Kinerja sesuai dengan harapan pengunjung yang berarti ketepatan waktu, pelayanan yang sama, untuk semua pengunjung tanpa kesalahan, sikap yang simpatik, dan dengan akurasi yang tinggi. Selama penelitian, Lembaga Pemasyarakatan Kelas IIA Denpasar sudah memberikan pelayanan sesuai yang dijanjikan secara akurat dan terpercaya. Seperti ketepatan waktu, pegawai melaksanakan kunjungan sesuai dengan jadwal yang sudah ada. Pegawai juga sudah memberikan pelayanan yang sama dan adil kepada pengunjung dan warga binaan.

Ketiga, Responsiveness, pegawai Lembaga Pemasyarakatan Kelas IIA Denpasar membantu dan memberi pelayanan yang cepat (responsive) dan tepat kepada pengunjung dengan adanya IT atau Sistem Database Pemasyarakatan, serta dengan fitur-fitur yang ada di SDP, penyampaian informasi pun menjadi lebih cepat dan jelas. Pengunjung sudah tidak menunggu lama dengan adanya Sistem Database Pemasyarakatan dan pendaftaran online.

Keempat, Assurance, pegawai Lembaga Pemasyarakatan Kelas IIA Denpasar sudah menumbuhkan rasa percaya kepada pengunjung, konunikasi pegawai sudah bagus, pegawai selalu memberitahukan informasi kepada pengunjung. Contohnya apabila tanggal merah, pegawai sudah memberitahukan kepada pengunjung apabila kunjungan libur dikarenakan tanggal merah. Dengan halhal kecil seperti itu pengunjung merasa senang karena telah diingingatkan. Kemudian dari sikap dan perbuatan pegawai Lembaga Pemasyarakatan Kelas IIA Denpasar ramah-ramah, baik dan sopan. Ramah dari segi pelayanannya, tidak pernah bentak-bentak, menegur pun secara halus, serta sopan kepada pengunjung yang datang, perkatannnya baik dan tidak pernah berkata kasar. 
Hasil observasi ini dibuktikan dengan pernyataan dari pengunjung mengenai sikap petugas dalam pelayanan kunjungan.

Kelima, Emphaty, berdasarkan observasi, para petugas menunjukkan sikap yang baik kepada pengunjung, berusaha untuk memahami keinginan pengunjung, dan memberikan pelayanan yang cepat. Apabila ada pengunjung yang melakukan kekeliruan, petugas memberi saran. Pegawai Lapas Perempuan Kelas IIA Denpasar sudah memberikan perhatian yang tulus, yang semua itu dapat dilihat dari sikap petugas yang ramah, sopan, dan tidak membentakbentak.

\section{KESIMPULAN}

Dari penelitian dan analisis yang dilakukan peneliti terhadap implementasi pelayanan kunjungan yang berbasis IT (Information Technology) serta kendala yang dihadapi di Lembaga Pemasyarakatan Perempuan Kelas IIA Denpasar, maka dapat disimpulkan bahwa implementasi pelayanan kunjungan sekarang ini khususnya yang telah berbasis IT pada Lembaga Pemasyarakatan Perempuan Kelas IIA Denpasar sudah diterapkan sesuai dengan prosedurnya, bahwa pelayanan kunjungan menggunakan Sistem Database Pemasyarakatan dan bisa menggunakan pendaftaran online. Selain itu, bagi pengunjung yang tempat tinggalnya jauh dari lapas dapat melakukan kunjungan melalui video call untuk efisiensi waktu, pemeriksaan yang dilakukan dengan menggunakan peralatan yang canggih seperti X-ray. Pelayanan berlangsung cepat, pengunjung diberikan tempat yang nyaman dalam menunggu, keterbukaan pun diberikan sesuai dengan porsinya. Sehingga walaupun masih terdapat kekurangan namun dapat diminimalisir dengan pelayanan yang jujur, cepat, dan baik.

Proses pelayanan kunjungan sudah lebih efektif terutama mengatasi pungutan liar yang selama ini terjadi untuk mempercepat proses pelayanan, dengan telah teritegrasikan dengan IT pelayanan yang diberikan sudah dapat dijalankan dengan lebih tertib.

Manfaat dengan adanya pelaksanaan kunjungan berbasis IT yaitu (1) Keadilan. Unsur keadilan pun dapat terlaksana dengan baik pada pelayanan kunjungan berbasis IT ini, semua pengunjung mendapatkan informasi yang mereka butuhkan sama dengan pengunjung lainnya, karena IT membantu untuk wujud dari keterbukaan informasi publik yang dibatasi sesuai ketentuan yang berlaku, namun seluruh pengunjung akan mendapatkan informasi yang sama, 
jadi tidak ada lagi kekhususan terhadap pengunjung tertentu semua pengunjung diberikan hak yang sama sesuai dengan porsinya sebagai pengunjung; (2) Kenyamanan, dengan adanya IT, tentu pengunjung akan lebih nyaman karena pelayanannya yang cepat dan tidak berbelit-belit, dengan adanya fitur nomor panggilan antrian pada SDP, tentu itu membuat pengunjung lebih nyaman karena informasi yang disampaikan jelas; (3) Kepuasan, dari penelitian yang dilakukan penulis, kepuasan pengunjung pun meningkat dengan adanya IT, hal tersebut dapat dilihat dari laporan tingkat kepuasan pengunjung setiap bulannya, tingkat ketidakpuasan sangat minim; (4) Ketertiban, dengan adanya IT ketertiban pun menjadi meningkat, pelayanan menjadi lebih tertata dan terstruktur. Hal tersebut dapat dilihat dari tidak adanya keributan dalam pelaksanaan kunjungan; (5) Kecepatan dan ketepatan, segala informasi dan pelayanan menjadi cepat dan tepat dengan IT. Di dalam aplikasi SDP sudah ada fitur biometric, jadi semua data warga binaan sudah ada, dengan adanya aplikasi tersebut maka petugas pun tidak akan salah dalam memanggil warga binaan yang dikunjungi.

Di balik banyaknya perubahan yang tentunya dianggap lebih baik oleh masyarakat khususnya yang menerima pelayanan kunjungan tersebut, tentu terdapat kendala yang masih menghambat pelaksanaan pelayanan kunjungan yang berbasis IT seperti, jaringan internet yang terkadang kurang baik, kurangnya pengetahuan pengunjung tentang IT, serta kurangnya sarana dan prasarana.

\section{DAFTAR PUSTAKA}

Abidin, S.Z. (2019). Kebijakan Publik. (edisi 4). Jakarta: Salemba Humanika Dwiyanto, A., dkk. (2010). Reformasi Birokrasi Publik di Indonesia. Jakarta: Gadjah Mada University Press.

Hardiyansyah. (2018). Kualitas Pelayanan Publik: Konsep, Dimensi, Indikator dan Implementasinya. Yogyakarta: Gavamedia

Keputusan Menteri Kehakiman Republik Indonesia Nomor M.04.PR.07.03

Tahun 1985 Tentang Organisasi dan Tata Kerja Rutan dan Rupbasan

Keputusan Menteri Pendayagunaan Aparatur Negara Nomor 63 tahun 2003

Tentang Pedoman Umum Penyelenggaraan Pelayanan Publik

Mindarti, L.I. (2016). Manajemen Pelayanan Publik: Menuju Tata Kelola yang Baik. Malang: UBPress 
Moleong, L.J. (2017). Metodologi Penelitian Kualitatif. Bandung: PT Remaja Rosdakarya Offse

Parasuraman, A., Berry, L., and Zeithaml, V.A. (1985). "A Conceptual Model of Service Quality and Its Implications for Future Research". Journal of Marketing, 49 (Fall), pp. 41-50.

Permana, R.A., dan Rudatyo, H.M. (2017). Pelaksanaan Sistem Layanan Kunjungan Bagi Warga Binaan Pemasyarakatan di Rumah Tahanan Negara Wonogiri, Dalam Rangka Peningkatan Pelayanan Kepada Publik Berdasarkan UU No 12 Tahun 1995 Tentang Pemasyarakatan. Surakarta: Fakultas Hukum, Universitas Islam Batik.

Pusat Pembinaan dan Pengembangan Bahasa. (1990). Kamus Besar Bahasa Indonesia. Jakarta: Departemen Pendidikan dan Kebudayaan.

Peraturan Menteri Hukum dan HAM RI Nomor M.HH-01.IN.04.03 tahun 2011 tentang Pengelolaan dan Pelayanan Informasi dan Dokumentasi pada Direktorat Jenderal Pemasyarakatan, Kantor Wilayah Hukum dan HAM, dan Unit Pelaksana Teknis Pemasyarakatan. Bphn.go.id. Diakses dari https://bphn.go.id/data/documents/m.hh-01.in,04.03 tahun 2011.pdf

Peraturan Menteri Hukum dan Hak Asasi Manusia Republik Indonesia Nomor 39 tahun 2016 Tentang Sistem Database Pemasyarakatan. Ditjenpp. kemenkumham.go.id. Diakses dari http://ditjenpp.kemenkumham.go.id/ arsip/bn/2016/bn1744-2016.pdf

Simarmata, J. (2006). Pengenalan Teknologi Komputer dan Informasi. Yogyakarta: Andi Offset.

Taufiqurokhman. (2014). Kebijakan Publik: Pendelegasian Tanggung Jawab Negara kepada Presiden Selaku Penyelenggara Pemerintahan. Jakarta: FISIP, Universitas Moestopo Beragama Pers. Diakses dari https:// moestopo.ac.id/wp-content/uploads/2016/08/Kebijakan-Publik-OlehDr.-Taufiqurokhman.-M.Si .pdf

Undang-Undang Republik Indonesia Nomor 12 Tahun 1995 Tentang Pemasyarakatan.

Undang-Undang Republik Indonesia Nomor 25 Tahun 2009 tentang Pelayanan Publik.

Undang-Undang Republik Indonesia Nomor 14 Tahun 2008 Tentang Keterbukaan Informasi Publik. 